\title{
The Cleared Mammary Fat Pad Transplantation Assay for Mammary Epithelial Organogenesis
}

\author{
Devon A. Lawson, ${ }^{1}$ Zena Werb, ${ }^{1}$ Yang Zong, ${ }^{2}$ and Andrew S. Goldstein ${ }^{3,4,5,6,7}$ \\ ${ }^{1}$ Department of Anatomy and Biomedical Sciences Program, University of California, San Francisco, California \\ 94143; ${ }^{2}$ Howard Hughes Medical Institute, University of California, Los Angeles, California 90095; ${ }^{3}$ Department \\ of Molecular and Medical Pharmacology, University of California, Los Angeles, California 90095; ${ }^{4}$ Department \\ of Urology, University of California, Los Angeles, California 90095; ${ }^{5}$ Jonsson Comprehensive Cancer Center, \\ David Geffen School of Medicine, University of California, Los Angeles, California 90095; ${ }^{6}$ Eli and Edythe Broad \\ Center of Regenerative Medicine and Stem Cell Research, University of California, Los Angeles, California 90095
}

Cleared mammary fat pad (MFP) transplantation has been a standard technique for studies of mammary development and cancer for several decades. The mammary gland is comprised of several fundamental components: The epithelial compartment contains basal/myoepithelial cells and luminal cells, and the stromal compartment (called the MFP) contains adipocytes, smooth muscle cells, fibroblasts, and immune cells. In 3- to 4-wk-old female mice, the mammary epithelium is concentrated very close to the nipple and has not yet grown beyond the mammary lymph node to penetrate the bulk of the MFP. This developmental feature provides an anatomical fixed point, and enables one to cut away the portion of the MFP from the nipple to the lymph node, leaving behind the majority of the MFP free of epithelium. The "cleared" MFP can serve as a supportive native microenvironment fully sufficient for the organogenesis of injected donor epithelium. Normal mammary epithelial donor cells will produce histologically and functionally normal mammary ductal epithelium several weeks posttransplant, with the exception that the ducts will not be connected to the nipple. The assay described here provides a powerful platform for assessing the developmental and tumorigenic potential of engineered cells of interest.

It is essential that you consult the appropriate Material Safety Data Sheets and your institution's Environmental Health and Safety Office for proper handling of equipment and hazardous material used in this protocol.

RECIPES: Please see the end of this protocol for recipes indicated by $<R>$. Additional recipes can be found online at http://cshprotocols.cshlp.org/site/recipes.

Reagents

Avertin (2,2,2-tribromoethanol and tertiary amyl alcohol)

Betadine

BSA coating solution $<\mathrm{R}>$

Carmine Alum (optional; see Step 23)

Collagenase solution $<\mathrm{R}>$

\footnotetext{
${ }^{7}$ Correspondence: andrew.goldstein@ucla.edu

(C) 2015 Cold Spring Harbor Laboratory Press

Cite this protocol as Cold Spring Harb Protoc; doi:10.1101/pdb.prot078071
} 
DMEM/F12

DNase I

Ethanol (70\%)

Fetal bovine serum (FBS) (heat-inactivated)

Hanks' Balanced Salt Solution (HBSS) $\left(\mathrm{Ca}^{2+} / \mathrm{Mg}^{2+}\right.$-free $)$

Matrigel-GFR (growth factor reduced) (BD Biosciences 354230)

Mice

Donor $(42+d$ old $)$

Recipient (21-28 d old)

Epithelial cell transplantation must be done syngeneically or into immune compromised mice.

Primary growth medium $<\mathrm{R}>$

Saline

Trypsin $(0.05 \%$ in EDTA)

Equipment

Cautery (high temperature, fine tip) (Bovie AA01)

Cell-culture hood

Centrifuge (benchtop)

Dissection equipment (scissors and tweezers)

Hemocytometer

Incubator

Microscope and slides (optional; see Step 23)

Scalpels

Shaker

Shaver

Surgical glue (Vetbond tissue adhesive; 3 M 1469SB)

Syringe (Hamilton)

Tissue-culture plates

Tissue-culture plates (low-attachment) (optional; see Step 11)

Tubes (10-mL conical)

Warming pad

Wound autoclips and EZ Clip applier

METHOD

To minimize the loss of donor cells that might adhere to the walls of the conical tubes during preparation, precoat all pipettes with BSA coating solution before tissue contact (Steps 7-16).

Dissociation of Mouse Mammary Tissue

1. Euthanize donor mice per institution guidelines. Sterilize each mouse with $70 \%$ ethanol.

2. Remove the mammary glands and place them into a tissue-culture plate containing DMEM/F12. In mice, there are five pairs of mammary glands (Fig. 1). The thoracic (\#3), abdominal (\#4), and inguinal (\#5) pairs can be harvested for epithelial cell dissociation.

3. Remove the lymph nodes from each of the abdominal (\#4) mammary glands.

4. In a laminar cell-culture hood, chop the tissues for 5-10 min with two scalpels on a tissueculture plate.

5. Transfer the minced tissues to $10-\mathrm{mL}$ conical tube containing $\sim 15 \mathrm{~mL}$ of collagenase solution. Place the tube on a shaker at $37^{\circ} \mathrm{C}$ for $30 \mathrm{~min}$.

This volume of collagenase solution is sufficient for up to 10 glands. 
D.A. Lawson et al.

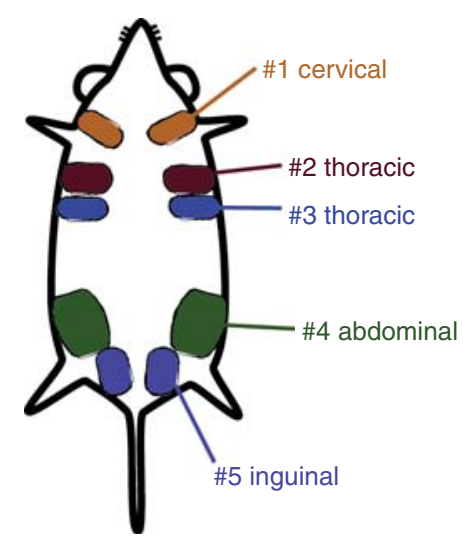

FIGURE 1. Mice possess five pairs of mammary glands, totaling 10 glands. \#1 cervical, \#2 and \#3 thoracic, \#4 abdominal, and \#5 inguinal are indicated.

6. Centrifuge the tube at $550 \mathrm{~g}$ for $10 \mathrm{~min}$ at $25^{\circ} \mathrm{C}$.

After centrifugation, the tube will have three layers: a fatty layer on top, an aqueous layer in the middle, and a pellet of cells and tissue fragments on the bottom.

7. Aspirate the fatty and aqueous layers, and resuspend the cell pellet in $10 \mathrm{~mL}$ of DMEM/F12. Centrifuge the tube at $550 \mathrm{~g}$ for $5 \mathrm{~min}$ at $25^{\circ} \mathrm{C}$. Repeat this step to remove all remaining traces of fat and enzyme.

8. Perform six rounds of differential centrifugation as follows.

i. Aspirate the supernatant.

ii. Resuspend the pellet in $10 \mathrm{~mL}$ of DMEM/F12.

iii. Pulse the cells in the centrifuge by spinning until the centrifuge reaches $550 g$, then stopping the spin.

Differential centrifugation will deplete dissociated cells such as stroma and immune cells present in the mammary gland and enrich for small epithelial tissue fragments called "organoids." For studies where these supporting cells are of interest, omit differential centrifugations.

9. Wash the organoids in $5 \mathrm{~mL}$ of HBSS and centrifuge at $550 \mathrm{~g}$ for $5 \mathrm{~min}$.

10. Resuspend the organoids in $2 \mathrm{~mL}$ of $0.05 \%$ trypsin/EDTA and incubate at $37^{\circ} \mathrm{C}$ for $10 \mathrm{~min}$ to dissociate cells.

11. (Optional) Near completion of the 10-min digestion (Step 10), transfer the digested organoids onto a low-adhesion plate and examine them under a microscope to confirm dissociation of the cells from the organoids.

12. Terminate the trypsinization using $2 \mathrm{~mL}$ of $2 \% \mathrm{FBS} / \mathrm{HBSS}$.

13. Pellet the cells at $550 \mathrm{~g}$ for $5 \mathrm{~min}$ and resuspend in $2 \mathrm{~mL}$ of HBSS.

14. Add $40 \mu \mathrm{L}$ of $1 \mathrm{mg} / \mathrm{mL}$ DNase I and incubate the cells at room temperature for 3-5 min.

15. Pellet the cells again and resuspend in $1 \mathrm{~mL}$ of primary growth medium. Determine the number of cells by counting using a hemocytometer.

16. Resuspend the desired cell number (ranging from $10^{3}$ to $10^{6}$ ) in $10 \mu \mathrm{L}$ of Matrigel-GFR: Primary Growth Medium 1:1 (v/v). Keep the Matrigel:medium mixture on ice until transplantation.

Each cleared MFP will be injected with a 10- $\mu$ L volume containing cells.

Cleared MFP Transplantation

17. Obtain appropriate recipient mice aged $21-28 \mathrm{~d}$. Anesthetize the mice with an intraperitoneal injection of $200-400 \mu \mathrm{L}$ of Avertin (2.5\%, diluted in saline).

18. Place a mouse on a plastic board with legs taped down. Shave the fur on the abdomen (unless the mouse is hairless) and wipe the abdominal skin with betadine and alcohol. 


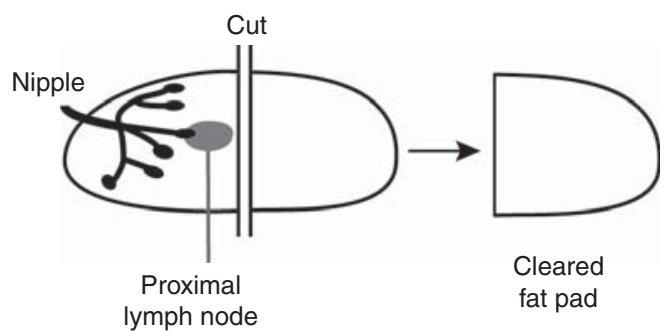

FIGURE 2. A single incision is made just after the mammary lymph node. The portion of the fat pad containing the mammary epithelial rudiment is removed, leaving behind a cleared fat pad ready for transplantation of donor epithelium.

19. Make a $1-\mathrm{cm}$ incision with scissors at the midline longitudinally starting at the belly button.

20. Make two $0.5-\mathrm{cm}$ incisions from the bottom of the midline incision to the hip region just above the leg. Pull the skin back from the peritoneum using forceps to expose the mammary gland and clamp down with an inverted tweezer.

21. To prevent excessive bleeding, use a handheld cauterizing device to sever three vessels before clearing the MFPs: Cauterize the mammary artery running between the \#4 and \#5 MFPs, as well as the two blood vessels that form a triangle around the proximal lymph node.

22. Cut the bridge between the \#4 and \#5 mammary glands with the cauterizing device to severe the connection between them.

This will prevent the epithelium from the \#5 gland from growing into the \#4 experimental MFP.

23. To remove the region of the MFP between the nipple and just after the proximal lymph node, first make one cut across the MFP just after the lymph node. Next, remove the portion of MFP between the lymph node and the mammary artery (Fig. 2).

(Optional) The tissue piece removed from the mammary glands can be spread on a microscope slide and stained with Carmine Alum to confirm that the entire rudimentary epithelial bud has been removed.

24. Load the cell/Matrigel mixture from Step 16 into a syringe for injection. Inject the cells into the remaining portion of the epithelium-free MFP between the inguinal lymph node and the midline.

25. Close the skin incisions with wound autoclips and surgical glue.

26. Repeat the procedure, if desired, on the contralateral mammary gland.

27. Place the mouse on a warming pad and monitor every 10-15 min until it regains consciousness. Monitor the mouse according to institutional guidelines for up to $1 \mathrm{wk}$ for signs of infection or other surgical complications.

\section{RELATED INFORMATION}

Cleared MFP transplantation was first showed in the pioneering work of DeOme et al. (1959); for more information, see Introduction: Tissue Recombination Models for the Study of Epithelial Cancer (Zong et al. 2014).

BSA Coating Solution

Reagent Final concentration

Phosphate-buffered saline (PBS) $1 \times$

Bovine serum albumin (BSA) $25 \mathrm{mg} / \mathrm{mL}$

Combine and shake until BSA is dissolved ( $\sim 15 \mathrm{~min})$. Filter sterilize through a $0.2-\mu \mathrm{m}$ filter. 
D.A. Lawson et al.

Collagenase Solution

Reagent

Final concentration

DMEM/F12

$1 \times$

Fetal bovine serum (FBS)

$5 \%$

Gentamicin

$50 \mu \mathrm{g} / \mathrm{mL}$

Insulin

$5 \mu \mathrm{g} / \mathrm{mL}$

Trypsin

$2 \mathrm{mg} / \mathrm{mL}$

Collagenase

$2 \mathrm{mg} / \mathrm{mL}$

Combine reagents and shake at $37^{\circ} \mathrm{C}$ until collagenase is dissolved $(\sim 15 \mathrm{~min})$. Filter sterilize through a $0.2-\mu \mathrm{m}$ filter. Store at $4^{\circ} \mathrm{C}$ for up to $1 \mathrm{mo}$.

Primary Growth Medium

Reagent

Final concentration

DMEM/F12

Insulin-transferrin-selenium (ITS)

$1 \times$

Epidermal growth factor (EGF)

Fetal bovine serum (FBS)

$1 \times$

Gentamicin

$50 \mathrm{ng} / \mathrm{mL}$

$5 \%$

Penicillin/streptomycin

$50 \mu \mathrm{g} / \mathrm{mL}$

ACKNOWLEDGMENTS

D.A.L. is supported by the Congressionally Directed Breast Cancer Research Program, U.S. Department of Defense (D.A.L., W81XWH-11-1-0742). W.Z. is supported by R01 CA057621.

\section{REFERENCES}

DeOme KB, Faulkin LJ Jr, Bern HA, Blair PB. 1959. Development of mammary tumors from hyperplastic alveolar nodules transplanted into gland-free mammary fat pads of female $\mathrm{C} 3 \mathrm{H}$ mice. Cancer Res 19: $515-520$.
Zong Y, Goldstein AS, Witte ON. 2014. Tissue recombination models for the study of epithelial cancer. Cold Spring Harb Protoc doi: 10.1101/pdb. top069880. 


\section{The Cleared Mammary Fat Pad Transplantation Assay for Mammary Epithelial Organogenesis}

Devon A. Lawson, Zena Werb, Yang Zong and Andrew S. Goldstein

Cold Spring Harb Protoc; doi: 10.1101/pdb.prot078071

\begin{tabular}{rc}
$\begin{array}{r}\text { Email Alerting } \\
\text { Service }\end{array}$ & Receive free email alerts when new articles cite this article - click here. \\
\hline $\begin{array}{r}\text { Subject } \\
\text { Categories }\end{array}$ & $\begin{array}{c}\text { Browse articles on similar topics from Cold Spring Harbor Protocols. } \\
\text { Developmental Biology (728 articles) } \\
\text { Mouse (437 articles) }\end{array}$ \\
& \\
\hline
\end{tabular}

